\title{
Species Richness of Adult Odonata in Labo River, Ozamiz City, Philippines
}

\author{
Emmarie F. Mapi-ot and Marie Rosellynn C. Enguito \\ Natural Sciences Department, College of Arts and Sciences, \\ Misamis University, Ozamiz City, Philippines \\ Corresponding author: Emmarie F. Mapi-ot, email: efmapiot@yahoo.com
}

\begin{abstract}
Dragonflies and damselflies of the order Odonata are well-known invertebrates and are of great ecological importance. They are among the biological indicators of environment quality. This study aimed to examine the species richness of adult Odonata in Labo River, Ozamiz City. Fieldwork was conducted from October 2013 to February 2014 in three sampling sites for a total of 122 man-hours. Opportunistic sampling method using sweep nets was employed. Twenty-one species under 16 genera and four families were recorded of which five species are endemic. Thirteen species belong to the suborder Anisoptera and eight to Zygoptera. The low species richness and the presence of indicator species of environmental disturbance imply that the sites sampled are already disturbed. The presence of endemic species within the area suggests the urgent need to employ conservation measures. Further surveys should also be done to have a complete database of the Odonata species in Labo River.
\end{abstract}

Keywords: damselflies, dragonflies, endemic, indicators, invertebrates 


\section{Introduction}

About 5,952 extant species of Odonata under 30 families and 652 genera have been described, of which 2,941 belong to the suborder Zygoptera (18 families, 308 genera), 3,011 to the Anisoptera (11 families, 344 genera), and two species in one genus to the suborder Anisozygoptera (Dijkstra et al., 2013). Most of these species are distributed within the tropics, where the greatest number and diversity occur in forested regions (Nelson et al., 2011).

Adult Odonata are most often seen near bodies of water, however, many species can thrive in distant habitat from water (Acquah-Lamptey, 2013). Immature Odonata also occupy a great diversity of aquatic habitats but are generally most abundant in lowland streams and ponds. All known species are predators and they perform as biological control agents against harmful insects such as mosquitoes (Kiany \& Minaei, 2009). The use of the Odonata as environmental quality indicator had been the subject of debate. It may be argued that, because of the complex requirements of habitat of each species, the presence of a vigorous and diverse fauna of these insects will always be a reliable indicator of stability, health, and integrity of an aquatic ecosystem (Foote \& Hornung, 2005). Nevertheless, Odonata communities have become an increasingly important tool in studies on the ecological evaluation of aquatic systems (Osborn, 2005; Bulánková, 1997).

Presently, the Philippines is known to have 280 species of Odonata and 40 new species await further description (Hämäläinen, 2012). Mindanao is the second largest island in the Philippine archipelago and it has extensive lists of interesting flora and fauna, some of which are endemic to the island or in a particular region of the island and has over a hundred species of Odonata (Villanueva \& Mohagan, 2010). Several surveys were done in poorly explored areas in Mindanao but still new species and new island records are still regularly found. Villanueva and Cahilog $(2012,2013)$ reported new island records and some are potentially new to science in their recent surveys in some parts of Mindanao including Tawi-Tawi, Sanga-Sanga and Jolo islands and in Talaingod, Davao del Norte. Quisil et al. (2013) found two species which are new Mindanao record during their surveys in Lanuza and San Agustin, Surigao del Sur. 
Labo River in Mindanao is one of the water systems in Ozamiz City that provide the water needs of the population. However, this river system has been modified for agricultural and other human uses. Untreated human sewage, urban development, logging and pollution have negative impacts on the river. There has been no study carried out on Odonata in Labo River. This study determined the species richness, species composition and biodiversity indices of Odonata in Labo River in Ozamiz City.

\section{Materials and Methods}

\section{Sampling area}

Sampling was conducted upstream, midstream and downstream in Labo River, Ozamiz City from October 2013 to February 2014 for a total of 122 man-hours. Sampling sites are shown in Figure 1.

Sampling Site 1 (upstream) is located in Barangay Gala, Ozamiz City. This site is located 582.47 meters above sea level (masl) at $8^{\circ} 09^{\prime} 59.01$ ' $\mathrm{N} 123^{\circ} 41^{\prime} 50.59^{\prime}$ ' E. The sampling site has forested portion and can be reached via existing man-made trails. Farming of upland vegetables such as carrots (Daucus carota), spring onions (Allium wakegi), gingers (Zingiber officinale), cucumbers (Cucumis sp.), radish (Raphanus sp.), tomatoes (Solanum sp.), "sayote" (Sechium edule), and other crops including sweet potato (Ipomoea batatas), tubers, abaca (Musa textilis), and patches of corn (Zea mays) are very common in the area. "Alingatong" (Urtica sp.) as named by locals was also found along the trails. Inorganic fertilizers and pesticides carried off the site due to soil erosion are the main contaminants for upstream pollution.

Sampling Site 2 (midstream) is located in Barangay Pantaon, Ozamiz City. This site is located 129.86 masl at $8^{\circ} 09^{\prime} 44.28^{\prime}$ ' $\mathrm{N} 123^{\circ} 46^{\prime}$ 56.23 " E. Large tracts of agro-forestry were observed and quarrying was a common activity in the area.

Sampling Site 3 (downstream) is located in Barangay Lapasan, Clarin. The site is located at 16.15 masl at $8^{\circ} 11^{\prime} 12.30^{\prime \prime} \mathrm{N} 123^{\circ} 50^{\prime}$ 42.89' E. Corn fields (Zea mays) were common in the area. Domestic solid and liquid wastes of households and quarrying in commercial scale were the largest sources of pollution. 


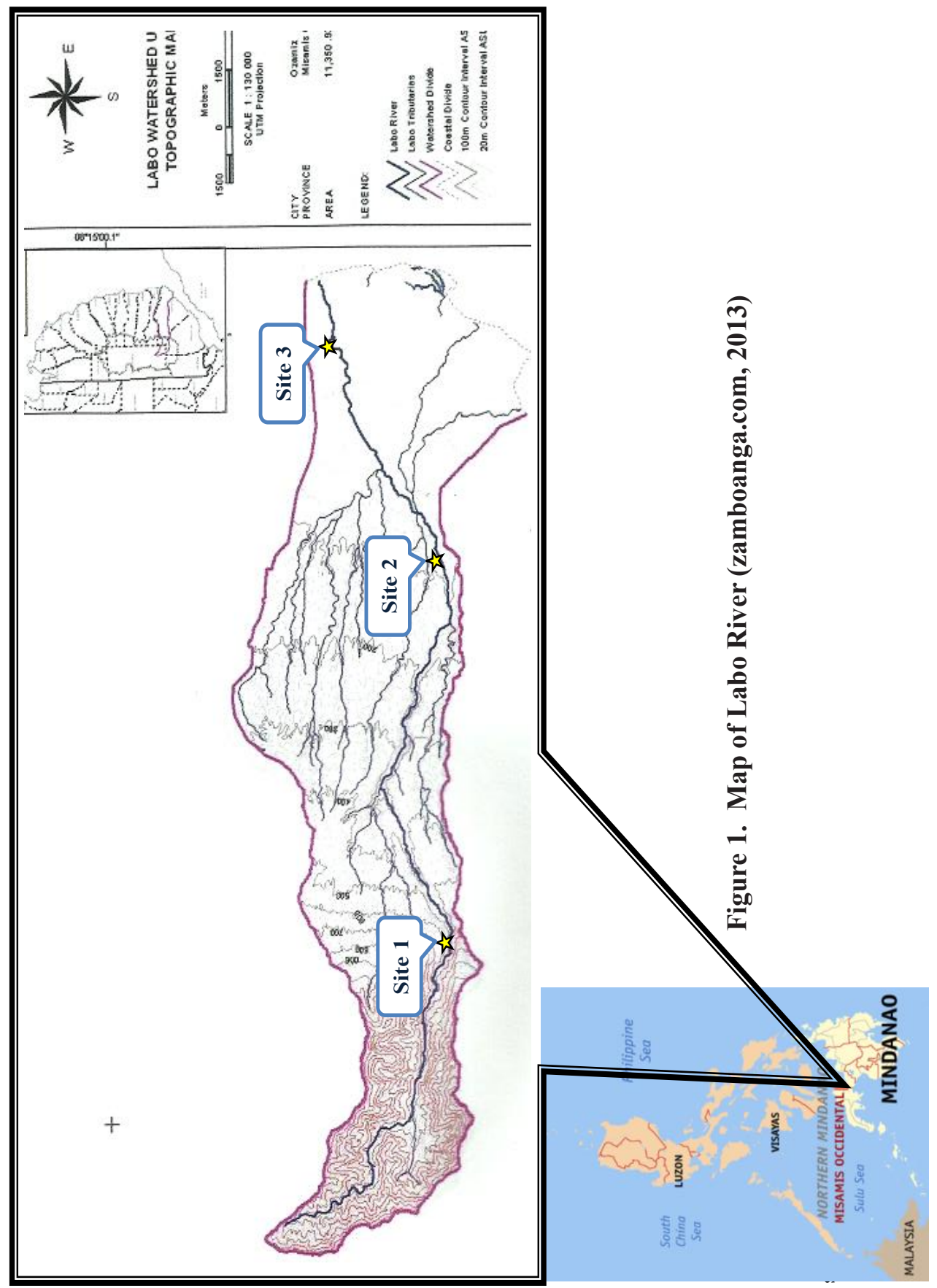




\section{Sampling, processing of samples, identification, and analysis of data}

Sweep nets were used in collecting the Odonata specimens. The collected samples were stored in small envelopes or folded paper triangles. The specimens were soaked in acetone for about 24 hours and dried completely. Identification was done using published photographs and pictorial keys and verified by an expert. Biodiversity indices were determined using BioDiversity PRO software version 2.0.

\section{Results and Discussion}

Twenty one species of Odonata comprising 13 Anisopterans and eight Zygopterans were identified from Labo River. These include five endemic species (Diplacina bolivari, Prodasineura integra, Risiocnemis atripes, Risiocnemis fuligifrons, and Teinobasis annamaijae) and 16 oriental species (Table 1). Endemic species were mostly under the suborder Zygoptera (damselfly) and only one endemic species (D. bolivari) was under the suborder Anisoptera (dragonfly). Among the Zygopterans, one species is Philippine endemic, two species are Greater Mindanao faunal region endemic and one species is Mindanao endemic. Two endemic Odonata species ( $D$. bolivari and $P$. integra) that are widespread in the country were recorded during the sampling.

Only one family (Libellulidae) under the suborder Anisoptera was recorded. Family Libellulidae comprises majority of the collected species $(\mathrm{N}=13)$. Libellulidae breeds principally in still water or lentic habitats, although larvae of some species are stream dwellers (Kiany \& Minaei, 2009). Larvae of most species are secretive, hiding among rotten vegetation at the bottom of the pond or lake; a few others have become secondarily adapted for a more active existence among growing vegetation (Gillott, 2005). Many species of Libellulidae can thrive in waters with low dissolved oxygen levels and a few species occupy brackish water habitats. Some species glide and migratory flights may be made up of several Libellulidae species (Tennessen, 2003). Recent surveys conducted in Mindanao (Aspacio et al., 2013; Jomoc et al., 2013; Malawani et al., 2013) also reported that majority of the species collected are under the family Libellulidae. 


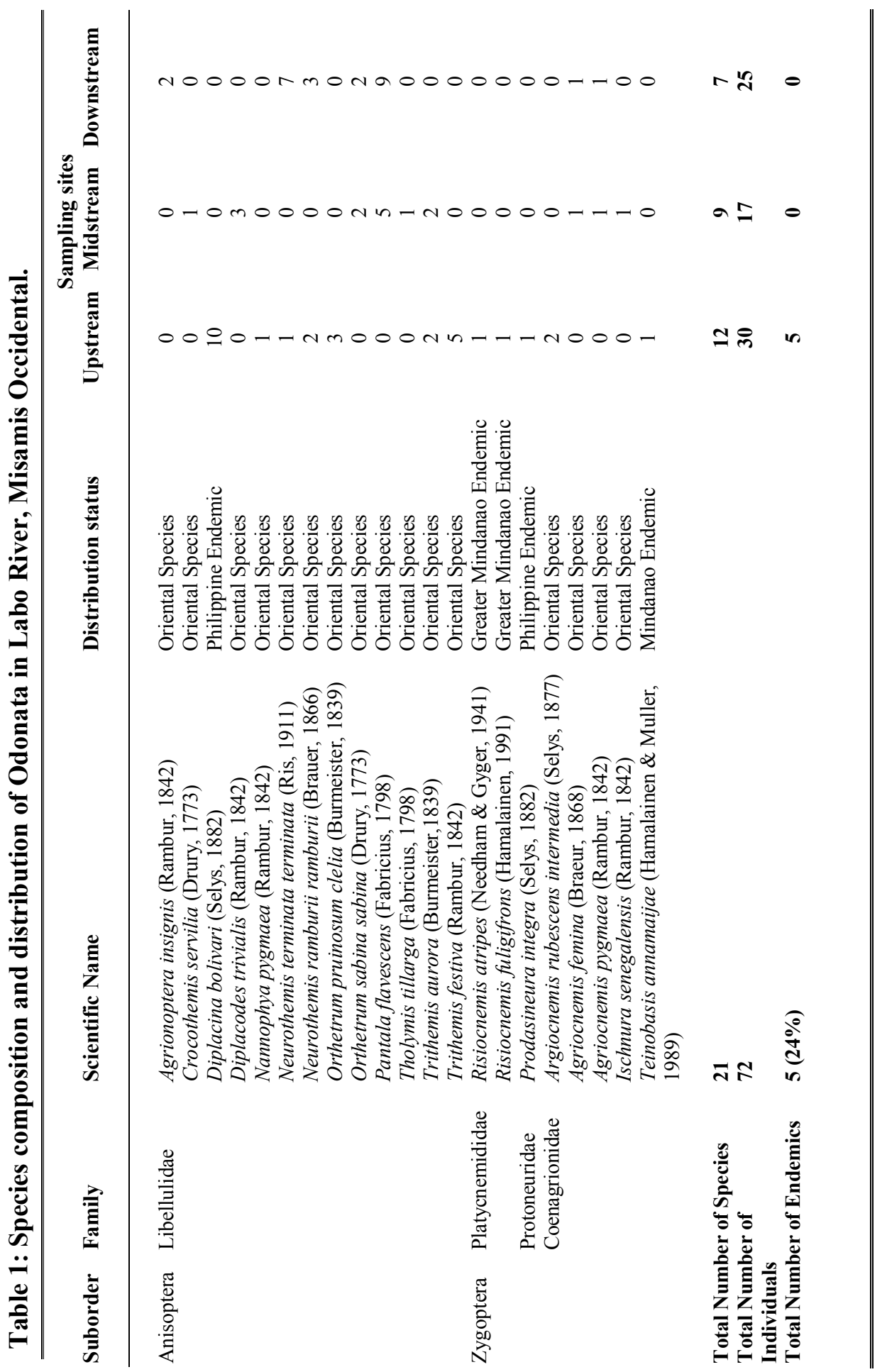


In this study, Site 1 (upstream) had the highest species richness (12), and all of the endemic species (5) collected were from this site. A widespread endemic species (D. bolivari) was the most abundant species $(\mathrm{N}=10)$. It is often encountered on forested streams and rivers perching on sun-exposed flat surface (Villanueva, 2012). Figures 2 and 3 show the two species under the genus Risiocnemis collected during the sampling. In Indo-Pacific region, the genus Risiocnemis is one of the most species-rich genera of the damselfly subfamily Calicnemiinae and it is endemic to the Philippines except for the Sulu archipelago and the Palawan island chain. Generally, the species of the genus are confined to small clear streams in shady rain forest environment, occurring from lowland up to lower montane forest (Gassmann \& Hämäläinen, 2002). The site had all the endemic species collected during the sampling because of its forested portion and it is less vulnerable to anthropogenic disturbances among all the sites assessed. This result showed that evergreen forest supports more endemic species (Subramanian et al., 2008).

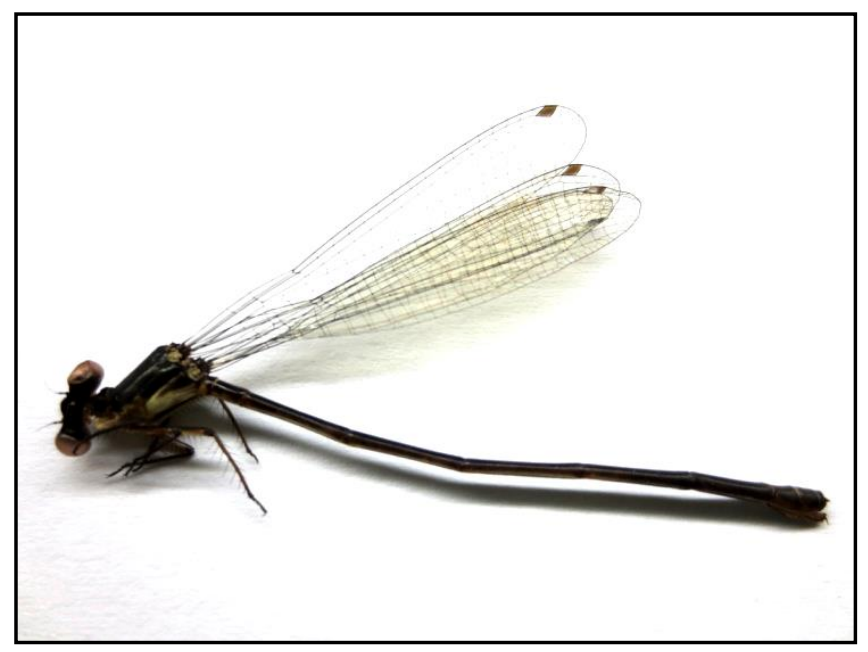

Figure 2. Risiocnemis atripes Needham \& Gyger, 1941; under Family Platycnemididae 


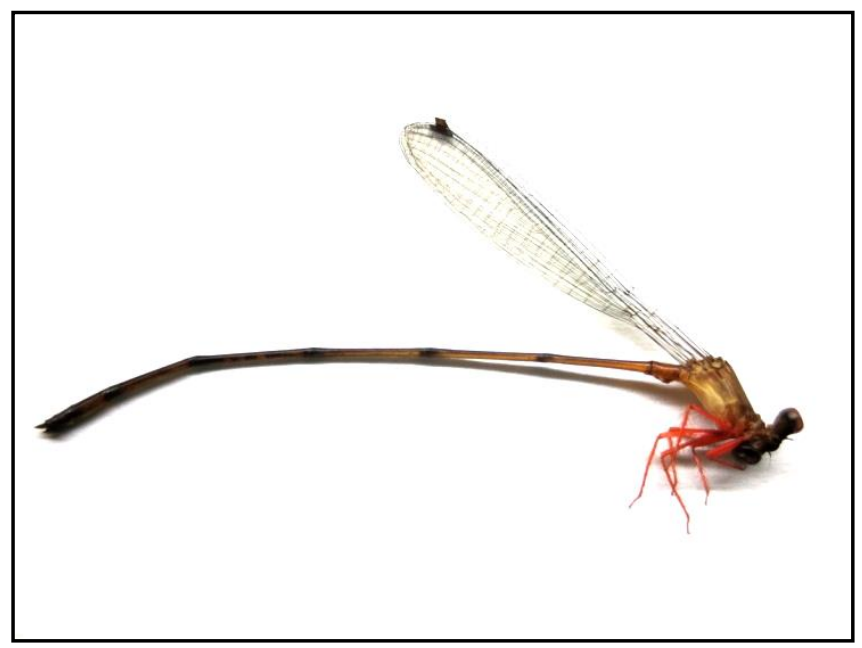

Figure 3. Risiocnemis fuligifrons Hamalainen, 1991; under Family Platycnemididae

In Site 2 (midstream), family Libellulidae was the most species-rich $(\mathrm{N}=6)$ family. Species under this family often inhabit open water. Libellulidae is the largest family of dragonflies comprising 140 genera and about 962 species (Tennessen, 2003) and considered to be the family that contains about a quarter of the known species of living Odonata. Recent studies conducted by Cayasan et al. (2013) reported that majority of the species they have collected belong to this family. The increasing freshwater width and lighter penetrating tree canopy can increase the number of dragonfly species (Clausnitzer, 2003).

Site 3 (downstream) had the lowest number of species $(\mathrm{N}=7)$ with no endemic species collected. Odonata is attracted to surfaces with reflective patterns such as crude oil because it recognizes water via polarized light. Attempts to oviposit on these surfaces which are very common in urbanized areas can be fatal to the Odonata species (Craves \& O'Brien, 2013). Pantala flavescens (Fabricius, 1798) was the abundant species collected $(\mathrm{N}=9)$. The species is an obligate migrant and it uses temporary ponds as breeding ground but may occasionally breed in permanent water (Boudot et al., 2013). Two widespread species of damselflies (Agriocnemis femina and Agriocnemis pygmaea) were found in the sampling site. Sato et al. (2008) found greater genetic differentiation in populations of several damselfly species occurring in highly fragmented 
urban habitats than in those found in rural areas. The sampling area is the most disturbed and it is more exposed to anthropogenic pressures causing it to have low species richness. Widespread and common species were found to be abundant because of their tolerance to human disturbances. Non-native plants which are relatively common in urban areas are threat to endemic Odonata (Samways \& Taylor, 2004).

In the present study, endemism of Odonata $(24 \%)$ is lower compared to the findings of Mapi-ot et al., (2013) in Montol River of Ozamiz City (50\%). The low endemism in Labo River could be attributed to habitat disturbance resulting from quarry activities and land use.

Shannon Diversity index was lowest in downstream $\left(\mathrm{H}^{\prime}=0.756\right)$, increasing in midstream $\left(\mathrm{H}^{\prime}=0.821\right)$ portion of the river and the highest diversity was found in the upstream $\left(H^{\prime}=0.919\right)$ (Figure 4). Site 1 (upstream) had the highest diversity and this was in accordance to the results of Sharma et al. (2007) that the presence of spring waters creates diversified microhabitat that can lead to higher species diversity. Generally, however, the three sites had low diversity which could be attributed to poor water quality (Domsic, 2008). Odonata species are sensitive to the change of environmental conditions and the types of habitat are a factor for species composition (Dolny et al., 2011). Labo River had an even distribution indicating the absence of a dominant species. Evenness value can be influenced by the competition of species for food and territory within an area (Malawani et al., 2013).

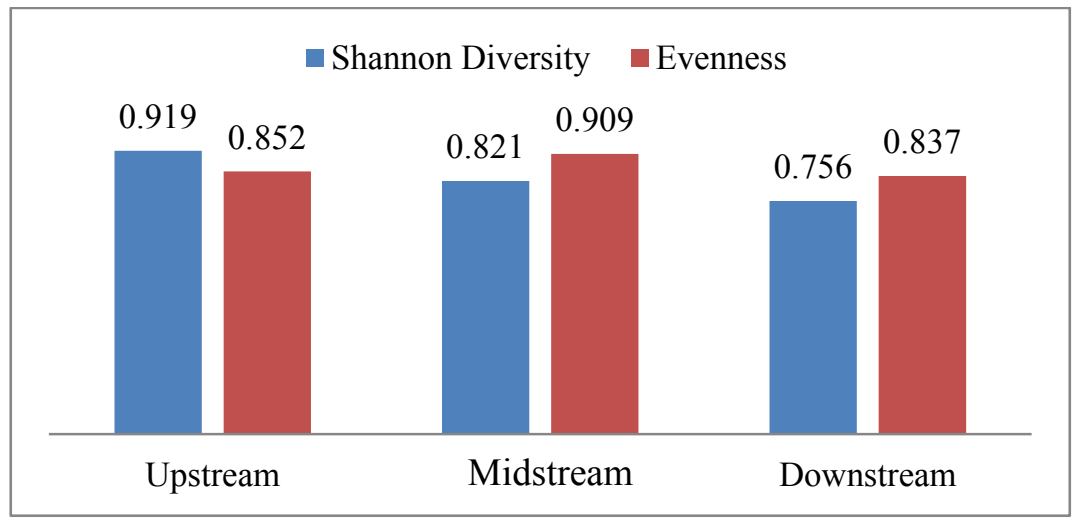

Figure 4. Shannon diversity index and evenness of Odonata in Labo River. 


\section{Conclusion and Recommendation}

Labo River has low species richness and low endemism of Odonata. The sampling sites are already disturbed as gauged from the high number of Oriental species and the presence of on-site disturbances.

The presence of five endemic species within the area suggests the urgent need to employ conservation measures to safeguard this vital ecosystem. It is also recommended that more field sampling should be done to have a complete database of the Odonata species in Labo River.

\section{Acknowledgment}

The researchers are grateful to the Misamis University for the financial support. We are also thankful to the Misamis University Community Extension Program (MUCEP) for providing us information and the map of Labo River. We are also grateful to Dr. Reagan Joseph Villanueva for the species identification and verification of the collected samples; and to Mr. Mark Anthony M. Manapsal for the good photographs of the specimens.

\section{Literature Cited}

Acquah-Lamptey, D., Kyerematen, R., \& Owusu, E. O. (2013). Using odonates as markers of the environmental health of water and its land related ecotone. International Journal of Biodiversity and Conservation, 5(11), 761-769. doi: 10.5897/IJBC2013.0600

Aspacio, K. T., Yuto, C. M., Nuñeza, O. M., \& Villanueva, R. J. T. (2013). Species diversity of Odonata in selected areas of Buru-un, Iligan City and Tubod, Lanao del Norte, Philippines. $A B A H$ Bioflux, 5(2), 145-155.

Boudot, J. P., Clausnitzer, V., Samraoui, B., Suhling, F., Dijkstra, K. D. B., \& Schneider, W. (2013). Pantala flavescens. In IUCN 2013. IUCN Red List of Threatened Species. Version 2013.2. $<$ www.iucnredlist.org $>$. Downloaded on 22 November 2013.

Bulánková, E. (1997). Dragonflies (Odonata) as bioindicators of environment quality. Biologia (Slovak Republic), 52(2), 177-180. 
Cayasan, R. D., Limitares, D. E., Gomid, J. V. S., Nuñeza, O. M., \& Villanueva, R. J. T. (2013). Species richness of Odonata in selected freshwater systems in Zamboanga del Sur, Philippines. AACL Bioflux, 6(4), 378-393.

Clausnitzer, V. (2003). Dragonfly communities in coastal habitats of Kenya: Indication of biotope quality and the need of conservation measures. Biodiversity and Conservation, 12(2), 333-356. doi: 10.1023/A:1021920402913

Craves, J. A., \& O'Brien, D. S. (2013). The Odonata of Wayne County, MI: Inspiration for renewed monitoring of urban areas. Northeastern Naturalist, 20(2), 341-362. doi: http://dx. doi.org/ $10.1656 / 045.020 .0210$

Dijkstra, K. D. B., Bechly, G., Bybee, S. M., Dow, R. A., Dumont, H. J., Fleck, G., ... \& Ware, J. (2013). The classification and diversity of dragonflies and damselflies (Odonata). In Z. Q. Zhang (Ed.), Animal biodiversity: An outline of higher-level classification and survey of taxonomic richness (Addenda 2013). Zootaxa, 3703(1), 36-45. doi: http://dx.doi.org/10.11646/zootaxa. 3703.1.9

Dolny, A., Bárta, D., Lhota, S., \& Drozd, P. (2011). Dragonflies (Odonata) in the Bornean rain forest as indicators of changes in biodiversity resulting from forest modification and destruction. Tropical Zoology, 24(1), 63-86.

Domsic, K. (2008). Odonata exuviae as indicators of wetland restoration success in Waterloo Region, Ontario. A Literature Review, 1-14. Retrieved from https://uwaterloo.ca/environment-resourcestudies/sites/ca.environment-resource-studies/files/uploads / files / 2009Domsic490.pdf

Foote, A. L., \& Hornung, C. L. R. (2005). Odonates as biological indicators of grazing effects on Canadian prairie wetlands. Ecological Entomology, 30(3), 273-283. doi: 10.1111/j.03076946.2005.00701.x 
Gassmann, D., \& Hämäläinen, M. (2002). A revision of the Philippine subgenus Risiocnemis (Igneocnemis) Hamalainen (Odonata: Platycnemididae). Tijdschrift voor Entomologie, 145(2), 213-266.

Gillott, C. (2005). Entomology (3rd ed.). Netherlands: Springer.

Hämäläinen, M. (2012). Odonata of the Philippines. In The champion in the sky-odonata. Exhibition booklet of the 2012 special exhibition (pp. 108-109). Kanagawa, Japan: Prefectural Museum of Natural History.

Jomoc, D. J. G., Flores, R. R. C., Nuñeza, O. M., \& Villanueva, R. J. T. (2013). Species richness of Odonata in selected wetland areas of Cagayan de Oro and Bukidnon, Philippines. AACL Bioflux, 6(6), 560-570.

Kiany, M., \& Minaei, K. (2009). The dragonfly family Libellulidae (Insecta: Odonata: Anisoptera) of Shiraz and its vicinity (Fars Province, Iran). Iran Agricultural Research, 28(1), 65-79.

Malawani, A. D., Ampang-Macabuat, N. M., Nuñeza, O. M., \& Villanueva, R. J. T. (2013). Odonata of Lanao del Sur, Mindanao, Philippines. International Research Journal of Biological Sciences, 3(1), 42-48.

Mapi-ot, E. F., Taotao, A. U., Nuñeza, O. M., \& Villanueva, R. J. T. (2013). Species diversity of adult Odonata in selected areas from Misamis Occidental Province, Philippines. AACL Bioflux, 6(4), 421-432.

Nelson, B., Ronayne, C., \& Thompson, R. (2011). Ireland Red List No. 6: Damselflies \& Dragonflies (Odonata). National Parks and Wildlife Service, Department of Environment, Heritage and Local Government, Dublin, Ireland. 
Osborn, R. (2005). Odonata as indicators of habitat quality at lakes in Louisiana, United States. Odonatologica, 34(3), 259 -270.

Quisil, S. J. C., Arreza, J. D. E., Nuñeza, O. M., \& Villanueva, R. J. T. (2013). Species richness of Odonata in Lanuza and San Agustin, Surigao del Sur, Philippines. AES Bioflux, 5(3), 245-260.

Samways, M. J., \& Taylor, S. (2004). Impacts of invasive alien plants on red-listed South African dragonflies (Odonata). South African Journal of Science, $100(1 \& 2), 78-80$.

Sato, M., Kohmatsu, Y., Yuma, M., \& Tsubaki, Y. (2008). Population genetic differentiation in three sympatric damselfly species in a highly fragmented urban landscape (Zygoptera: Coenagrionidae). Odonatologica, 37(2), 131-144.

Sharma, G., Sundararaj, R., \& Karibasvaraja, L. R. (2007). Species diversity of Odonata in the selected provenances of Sandal in Southern India. Zoos' Print Journal, 22(7), 2765-2767.

Subramanian, K. A., Ali, S., \& Ramachandra, T. V. (2008). Odonata as indicators of riparian ecosystem health a case study from South Western Karnataka, India. Fraseria, 7, 83-95.

Tennessen, K. J. (2003). Odonata (Dragonflies, Damselflies). In V. H. Resh \& R. T. Resh (Eds.). Encyclopedia of Insects (pp. 814-822). Hongkong: Academic Press.

Villanueva, R. J. T., \& Mohagan, A. B. (2010). Diversity and status of Odonata across vegetation types in Mt. Hamiguitan wildlife sanctuary, Davao Oriental. Asian Biojournal, 1(1), 25-35.

Villanueva, R. J. T. (2012). Alindanaw. Retrieved from http://alindanaw. com/about/studying-philippine-dragonfly-and-damselfly/diplacinabolivari/ 
Villanueva, R. J. T., \& Cahilog, H. (2012). Notes on a small Odonata collection from Tawi-Tawi, Sanga-Sanga and Jolo Islands, Philippines. International Dragonfly Fund-Report, 55, 1-32.

Villanueva, R. J. T., \& Cahilog, H. (2013). Small Odonata collection from Talaingod, Davao del Norte, Mindanao Island, Philippines. International Dragonfly Fund-Report, 59, 1-26.

zamboanga.com. (2013). Location of Misamis Occidental within the Philippines. Retrieved from http://www.zamboanga.com/z/ index.php?title $=$ Misamis_Occidental_Province,_Philippines 